\title{
Grain source and chromium supplementation: Effects on health, metabolic status, and glucose-insulin kinetics in Holstein heifer calves
}

\author{
Z. Habibi, ${ }^{1}$ S. Karimi-Dehkordi, ${ }^{1 *}$ S. Kargar, ${ }^{2 *} \dagger$ and M. Sadeghi ${ }^{3}$ \\ ${ }^{1}$ Department of Animal Science, College of Agriculture, Shahrekord University, Shahrekord 34141-88186, Iran \\ ${ }^{2}$ Department of Animal Science, School of Agriculture, Shiraz University, Shiraz 71441-65186, Iran \\ ${ }^{3}$ Zagros Milk and Meat Co., Shahrekord 88186-96465, Iran
}

\section{ABSTRACT}

Carbohydrate-rich diets may increase urinary excretion of chromium $(\mathrm{Cr})$ and the need to supplement the diet with $\mathrm{Cr}$ to meet animal requirements. The present study was performed to examine the effect of the type of grain (corn vs. barley) and Cr-methionine supplementation on health-related variables, blood levels of metabolites and hormones related to energy metabolism, and insulin sensitivity in Holstein calves. Forty-eight newborn heifers ( $3 \mathrm{~d}$ of age) were assigned randomly to 4 diets in a $2 \times 2$ factorial arrangement. Experimental diets were either corn-based (CBD) or barley-based (BBD) diets supplemented with 0 or 0.05 $\mathrm{mg} / \mathrm{kg}$ of metabolic body weight. Chromium was provided in milk before weaning (d 3-73 of age) and in prewarmed water after weaning (d 74-94 of age). There was no interaction between the type of grain and $\mathrm{Cr}$ on the health-related variables and blood metabolites and hormones. Type of grain did not affect fecal score, respiration rate, and rectal temperature; however, there were tendencies for higher diarrhea occurrence (odds ratio $=1.69)$ and lower chance of having pneumonia (odds ratio $=0.49$ ) in calves fed $\mathrm{BBD}$ versus $\mathrm{CBD}$ despite longer duration of diarrhea $(0.54 \mathrm{~d})$ and shorter days with pneumonia $(0.63 \mathrm{~d})$ in calves fed BBD. Calves supplemented with $\mathrm{Cr}$ had lower fecal score during the preweaning and overall periods and respiration rate throughout the study. Supplemental Cr decreased the duration $(0.63 \mathrm{~d})$ and chance of having pneumonia (odds ratio $=2.01$ ). Calves fed BBD had lower blood levels of urea $\mathrm{N}$ during the postweaning period, with no changes in other blood variables between CBD and BBD. Tendencies were detected for lower blood levels of $\beta$-hydroxybutyric acid during the preweaning and overall periods and higher cortisol in Cr-supplemented

Received March 14, 2019.

Accepted June 19, 2019.

*These authors contributed equally to this work.

†Corresponding author: skargar@shirazu.ac.ir calves. Chromium supplementation increased insulin clearance rate and decreased the time to half-maximal concentration and the area under the curve in $\mathrm{BBD}$ but not CBD calves. The calves were generally healthy, and the type of grain did not affect the health and blood variables related to energy metabolism. However, Cr supplementation increased fecal consistency, decreased respiration rate and days with pneumonia, and increased insulin sensitivity when added to BBD. Key words: calf, chromium-methionine, insulin sensitivity, starch source

\section{INTRODUCTION}

The nutritional and pharmacological advantages of chromium (Cr) for animals and humans have been well established (European Food Safety Authority Panel on Dietetic Products, Nutrition, and Allergies, 2014). Trivalent $\mathrm{Cr}$ is a component of chromodulin, a lowmolecular-weight Cr-binding substance contributing to signal autoamplification mechanism of insulin, thereby influencing the metabolism of carbohydrates, protein, and lipids (Pechova and Pavlata, 2007). The reported signs of $\mathrm{Cr}$ deficiency include impaired nutrient metabolism, lower sensitivity of the peripheral tissues to insulin, compromised immunity, and decreased weight gain and health status, specifically under stressful conditions (Kargar et al., 2018a,b; Mousavi et al., 2019b). A 10- to 300- fold increase in urinary excretion of $\mathrm{Cr}$ was suggested in animals exposed to stress or fed diets rich in carbohydrates (Pechova and Pavlata, 2007), implying the need for supplementation of the diet with exogenous Cr (Kargar et al., 2018a,b, 2019).

Corn and barley grains, containing a high level of starch, are commonly fed to ruminants worldwide. The slow ruminal fermentation rate of corn grains is associated with a higher quantity of starch available in the small intestine (Kargar et al., 2013, 2014), which supplies more energy (Khan et al., 2007). It is not clear how grains with different ruminal fermentation, especially in Cr-supplemented diets, affect the dairy calf 
energy metabolism. Kargar et al. (2019) showed that the type of grain in the starter diets did not affect calf performance, although they recorded a higher BW on the Cr-supplemented diets. The same study also demonstrated that the beneficial effect of supplemental $\mathrm{Cr}$ in increasing eating rate and rumination time may be dependent on the type of grain in the starter.

With increasing calf age, a state of insulin resistance may develop, which modifies glucose utilization in peripheral tissues (Jovanović et al., 2017; Kargar et al., 2018b); therefore, we hypothesized that $\mathrm{Cr}$ might critically contribute to the metabolism and to efficient nutrient turnover. Apart from our interest in examining whether the type of grain (corn vs. barley) and $\mathrm{Cr}$ supplementation would affect metabolism, we also hypothesized that the beneficial effects on weight gain by Cr supplementation and on eating rate and rumination time as a result of $\mathrm{Cr} \times$ grain type interaction may be due to modification of the variables involved in energy metabolism (e.g., glucose, insulin, triiodothyronine, thyroxine, and cortisol). The current study was therefore aimed at determining the effects of grain type and Cr supplementation in the starter diets on the health, circulatory concentration of selected metabolites and hormones related to energy metabolism, and sensitivity to insulin in Holstein heifer calves.

\section{MATERIALS AND METHODS}

\section{Environment, Calves, Treatments, and Management}

This trial was conducted from July 11 to November 18, 2015, at a local dairy farm (Zagros Milk and Meat Co., Shahrekord, Chaharmahal and Bakhtiari Province, Iran). Animal procedures were approved by the Animal Care Committee of Shahrekord University as outlined by the Iranian Council of Animal Care (1995). Air temperature and relative humidity in the stall areas were recorded daily by Hobo Pro Series Temp probes (Onset Computer Corp., Pocasset, MA). Temperature-humidity index was computed using the equation $\mathrm{THI}=(0.8$ $\times$ maximum $\mathrm{T})+($ minimum $\mathrm{RH} / 100) \times($ maximum $\mathrm{T}-14.4)+46.4$, in which $\mathrm{T}$ is the air temperature $\left({ }^{\circ} \mathrm{C}\right)$ and $\mathrm{RH}$ denotes the relative humidity (\%; Mader et al., 2006).

A total of 48 Holstein female calves [initial BW (d $3)=39.0 \pm 1.21 \mathrm{~kg} ;$ mean $\pm \mathrm{SE}$ ] were allotted to the treatment groups at $3 \mathrm{~d}$ of age and weaned on $\mathrm{d} 73$, and the experiment was continued until d 94 of age. The calves were housed in a naturally ventilated barn with individual pens $(1.2 \mathrm{~m} \times 1.0 \mathrm{~m} \times 1.0 \mathrm{~m}$; length $\times$ width $x$ height) bedded with rubber mattresses. The bedding was washed every $2 \mathrm{~d}$ and the manure removed daily. After birth, calves were fed a total of $5 \mathrm{~L}$ of colostrum, with $3 \mathrm{~L}$ fed within $2 \mathrm{~h}$ of life and $2 \mathrm{~L}$ fed $8 \mathrm{~h}$ after the first feeding. Colostrum was fed for the first $2 \mathrm{~d}$ of life. Calves were then individually fed pasteurized $\left(72.5^{\circ} \mathrm{C}\right.$ for 30 min) waste milk (containing $3.22 \pm 0.22 \%$ fat and $2.96 \pm 0.19 \% \mathrm{CP}$ ) in steel buckets in 2 equal meals (at 0700 and $1600 \mathrm{~h}$ ). Milk was fed using the step-up/ step-down procedure, and all calves were offered $4 \mathrm{~L}$ of milk/d from d 3 to $10,5 \mathrm{~L} / \mathrm{d}$ from d 11 to $20,6 \mathrm{~L} / \mathrm{d}$ from d 21 to $40,7 \mathrm{~L} / \mathrm{d}$ from d 41 to $50,6 \mathrm{~L} / \mathrm{d}$ from d 51 to $60,5 \mathrm{~L} / \mathrm{d}$ from d 61 to $63,4 \mathrm{~L} / \mathrm{d}$ from d 64 to 66,3 $\mathrm{L} / \mathrm{d}$ from d 67 to 69 , and $2 \mathrm{~L} / \mathrm{d}$ from d 70 to 73 of age.

The calves were randomly allocated to 4 experimental $\operatorname{diets}(\mathrm{n}=12 /$ diet $)$ in a $2 \times 2$ factorial arrangement: $(1)$ a corn-based diet (CBD) with no supplemental Cr, (2) a CBD with supplemental $\mathrm{Cr}\left(0.05 \mathrm{mg} / \mathrm{kg}\right.$ of $\left.\mathrm{BW}^{0.75}\right)$, (3) a barley-based diet (BBD) with no supplemental $\mathrm{Cr}$, and (4) a BBD with supplemental Cr $(0.05 \mathrm{mg} /$ $\mathrm{kg}$ of $\mathrm{BW}^{0.75}$; Table 1). Chromium [MicroPlex 1000, supplied 1,000 $\mathrm{mg}$ of $\mathrm{Cr} / \mathrm{kg}$ as Cr-Met (Cr-methionine, 90\% Met and 10\% Cr, wt/wt); Zinpro Corp. Inc., Eden Prairie, MN] was mixed with $300 \mathrm{~mL}$ of milk and fed in bottles before weaning to supply $0.05 \mathrm{mg}$ of $\mathrm{Cr} / \mathrm{kg}$ of $\mathrm{BW}^{0.75}$. The remaining milk was fed according to the milk feeding program. After weaning (d 73), the same dosage of Cr was mixed into $300 \mathrm{~mL}$ of prewarmed water $\left(39^{\circ} \mathrm{C}\right)$ and fed in bottles until the end of the trial (d 94). Calves not supplemented with $\mathrm{Cr}$ received $300 \mathrm{~mL}$ of milk or prewarmed water before and after weaning, respectively. The calves were weighed at birth, on d 3, and once weekly thereafter using an electronic scale, which was calibrated by the manufacturer's agent before initiation of the study and every month thereafter. Chromium supplementation was adjusted based on weekly BW (Kargar et al., 2019; Mousavi et al., 2019b). To measure $\mathrm{Cr}$ content in basal starter feeds $(\mathrm{n}=13$ / basal starter feed; 1 sample/wk) and individual refusals ( $\mathrm{n}=13 /$ calf; pooled by calf within treatment every week), representative subsamples were ground to pass a 1-mm screen in a Wiley mill (Ogawa Seiki Co. Ltd., Tokyo, Japan), prepared according to Mousavi et al. (2019b), and analyzed for Cr content (flame photometer; GBC Integra EXL ICP, Melbourne, Australia). Glasswares were acid washed to avoid sample contamination, and a blank was run with the samples to test for possible contamination. However, milk and drinking water were not analyzed for $\mathrm{Cr}$ content. Calves had unlimited access to fresh drinking water and were fed starter feed diets (formulated to meet their nutrient requirements; NRC, 2001) to provide at least $10 \%$ refusals. Ingredients and chemical composition of the basal diets are shown in Table 1. Initial (d 3) measurements for calves fed CBD without and with Cr supplementation and BBD without and with $\mathrm{Cr}$ supplementation, respectively, were as follows: BW, 38.88, 39.81, 38.52, 
Table 1. Ingredients and chemical composition of the experimental diets (DM basis) fed to calves

\begin{tabular}{|c|c|c|}
\hline \multirow[b]{2}{*}{ Item } & \multicolumn{2}{|c|}{$\operatorname{Diet}^{1}$} \\
\hline & CBD & $\mathrm{BBD}$ \\
\hline \multicolumn{3}{|l|}{ Ingredient, $\%$ of DM } \\
\hline Alfalfa hay & 5.0 & 5.0 \\
\hline Ground corn grain & 53.0 & - \\
\hline Ground barley grain & - & 57.0 \\
\hline Soybean meal & 29.8 & 29.8 \\
\hline Canola meal & 6.0 & 2.0 \\
\hline Extruded soybean & 2.5 & 2.5 \\
\hline Mineral mixture $^{2}$ & 1.5 & 1.5 \\
\hline Vitamin and mineral mixture ${ }^{3}$ & 1.0 & 1.0 \\
\hline Sodium bicarbonate & 1.0 & 1.0 \\
\hline Salt & 0.2 & 0.2 \\
\hline \multicolumn{3}{|l|}{$\begin{array}{l}\text { Chemical composition, } \\
\% \text { of DM unless noted }\end{array}$} \\
\hline DM, \% & 88.7 & 90.8 \\
\hline $\mathrm{CP}$ & 20.7 & 20.5 \\
\hline $\mathrm{NFC}^{4}$ & 51.9 & 51.0 \\
\hline $\mathrm{NDF}$ & 14.7 & 17.6 \\
\hline Ether extract & 3.9 & 3.2 \\
\hline Ash & 8.8 & 7.7 \\
\hline Calcium $^{5}$ & 0.6 & 0.7 \\
\hline Phosphorus $^{5}$ & 0.4 & 0.4 \\
\hline Chromium, $\mathrm{mg} / \mathrm{kg}$ of DM & 0.292 & 0.277 \\
\hline $\mathrm{ME},{ }^{5} \mathrm{Mcal} / \mathrm{kg}$ of DM & 3.11 & 2.94 \\
\hline $\mathrm{NE}_{\mathrm{M}},{ }^{5} \mathrm{Mcal} / \mathrm{kg}$ of DM & 2.33 & 2.20 \\
\hline $\mathrm{NE}_{\mathrm{G}},{ }^{5} \mathrm{Mcal} / \mathrm{kg}$ of DM & 1.77 & 1.67 \\
\hline
\end{tabular}

${ }^{1} \mathrm{CBD}=$ corn-based diet; $\mathrm{BBD}=$ barley-based diet.

${ }^{2}$ Contained per kilogram of supplement: $240 \mathrm{~g}$ of $\mathrm{Ca}, 65.7 \mathrm{~g}$ of $\mathrm{Mg}$, $20 \mathrm{~g}$ of $\mathrm{Zn}, 10 \mathrm{~g}$ of $\mathrm{Mn}, 5.29 \mathrm{~g}$ of $\mathrm{Cu}, 200 \mathrm{mg}$ of I, and $100 \mathrm{mg}$ of Co.

${ }^{3}$ Contained per kilogram of supplement: 1,500,000 IU of vitamin A, $250,000 \mathrm{IU}$ of vitamin $\mathrm{D}, 10,000 \mathrm{IU}$ of vitamin $\mathrm{E}, 0.2 \mathrm{~g}$ of biotin, 1.56 $\mathrm{g}$ of organic $\mathrm{Zn}, 0.84 \mathrm{~g}$ of organic $\mathrm{Mn}, 0.54 \mathrm{~g}$ of organic $\mathrm{Cu}$, and 40 $\mathrm{mg}$ of organic Se.

${ }^{4} \mathrm{NFC}=100-(\mathrm{CP}+\mathrm{NDF}+$ ether extract + ash $)(\mathrm{NRC}, 2001)$.

${ }^{5}$ Calculated from NRC (2001).

and $38.51 \mathrm{~kg}$; height girth, $74.4,73.9,73.5$, and 74.0 $\mathrm{cm}$; withers height, $76.5,77.1,76.8$, and $77.7 \mathrm{~cm}$; and hip width, $16.7,17.1,16.3$, and $16.8 \mathrm{~cm}$.

\section{Health Criteria}

Calf health checks were performed daily by a veterinarian who was blinded to the treatments. Respiration rate (RR) was measured at $1430 \mathrm{~h}$ every day by visual observation for 3 separate minutes according to the methods described by Kargar et al. (2015). Immediately after recording RR, rectal temperature (RT) was recorded using a digital thermometer (model FT 15/1; Beurer GmbH, Ulm, Germany) held in the calf rectum for $1 \mathrm{~min}$. Feces were scored daily according to the procedure of Pazoki et al. (2017) and categorized as firm and well-formed (score 1), soft and pudding-like (score 2), runny and pancake batter (score 3), and liquid and splatters (score 4). Fecal score was categorized as number of days with fecal score $\geq 3$ and denoted as days with abnormal fecal score. In the case of having fecal score $\geq 3$ as well as coughing or nasal discharge, the calves were examined by the veterinarian to confirm diarrhea or pneumonia diagnoses. The treatment procedures for diarrhea and pneumonia were those applied at the Zagros Milk and Meat Co. (Shahrekord, Iran). Treatments were discontinued in calves that did not respond to the treatment. Calves in general were healthy, and no animal died during the study.

\section{Blood Sampling and Analyses}

Jugular blood samples, collected into Vacutainer tubes (BD Vacutainer, Franklin Lakes, NJ) containing spray-coated silica, were prepared at $4 \mathrm{~h}$ after the morning feeding on d $3,13,23,33,43,53,63,73,83$, and 93 of age. Blood samples were immediately placed on ice and centrifuged at $3,000 \times g$ for $20 \mathrm{~min}$ at $4^{\circ} \mathrm{C}$, and $1.5 \mathrm{~mL}$ of serum was pipetted into $2-\mathrm{mL}$ cryotubes and stored at $-20^{\circ} \mathrm{C}$ for later analyses. Additional blood samples were taken on d 73 and 93 of calf life for hormone measurement. Concentrations of blood metabolites [including glucose $(\mathrm{mg} / \mathrm{dL}), \beta$-hydroxybutyric acid ( $\boldsymbol{\beta H B A} ; \mathrm{mmol} / \mathrm{L})$, BUN (mg/dL), cholesterol $(\mathrm{mg} / \mathrm{dL})$, triglyceride $(\mathrm{mg} / \mathrm{dL})$, total protein $(\mathrm{g} / \mathrm{dL})$, and albumin $(\mathrm{g} / \mathrm{dL})$ ] and hormones [including insulin $(\mu \mathrm{IU} / \mathrm{mL})$, triiodothyronine $\left(\mathbf{T}_{3} ; \mathrm{ng} / \mathrm{dL}\right)$, thyroxine $\left(\mathbf{T}_{4} ; \mu \mathrm{g} / \mathrm{dL}\right)$, and cortisol $\left.(\mu \mathrm{g} / \mathrm{dL})\right]$ were measured using commercially available kits as described by Kargar et al. (2018a,b). Globulin (g/dL) concentrations were computed by subtracting albumin from total protein contents.

\section{Intravenous GTT}

Glucose tolerance test (GTT) was conducted at the end of the postweaning period using 32 calves ( 8 calves/ treatment) according to the procedure described earlier by Yari et al. (2010). Pharmacokinetic parameters in response to intravenous GTT for glucose and insulin, including basal levels, relative disposal rate $(\% / \mathrm{min}$, 20-120 min), and time to half-maximal concentration $\left(\mathbf{T}_{1 / 2} ; \mathrm{min}\right)$, were calculated. The positive incremental area under the curve $(\mathbf{A U C} ; \mu \mathrm{IU} / \mathrm{mL} \times 120 \mathrm{~min})$ for glucose and insulin was also computed using the trapezoid rule with baseline subtraction (Mousavi et al., 2019a,b).

\section{Statistical Analyses}

Data on daily $\mathrm{Cr}$ intake, RR, RT, and blood variables (10-d period) were analyzed for preweaning (d 3-73), postweaning (d 74-94), and overall (d 3-94) periods 
using the MIXED MODEL procedure (SAS 9.4, SAS Institute Inc., Cary, NC) with time (1- or 10-d period) as repeated measures. The effect of dietary treatments on the categorical responses related to fecal score was analyzed using PROC GLIMMIX with repeated measures. Calf was considered as a random effect, and the type of grain (G; corn vs. barley), $\mathrm{Cr}$ supplement (0 vs. $0.05 \mathrm{mg} / \mathrm{kg}$ of $\left.\mathrm{BW}^{0.75}\right), \mathrm{G} \times \mathrm{Cr}$, time, $\mathrm{G} \times$ time, $\mathrm{Cr} \times$ time, and $\mathrm{G} \times \mathrm{Cr} \times$ time were considered as fixed effects. The lowest Akaike information criterion (fit statistic) level was used to select the covariance structure, and the auto-regression structure (type 1) was accordingly modeled. Data on blood hormones (at weaning and at the end of the trial) and GTT were analyzed using the same model without the time effect. Initial (d 3) blood variables were used as covariates for the blood metabolite analyses. Data were reported as least squares means and were considered significant if $P \leq 0.05$ and a tendency if $0.05<P \leq 0.10$. When the interaction between $\mathrm{G}$ and $\mathrm{Cr}$ was significant, the SLICE option in the LSMEANS statement was used to determine differences among the factors.

Models for the occurrence of diarrhea $(\geq 3)$ or pneumonia were examined by logistic regression using a binomial distribution in PROC GLIMMIX. The odds ratio was used to compare the likelihood for calves on each experimental diet to experience any event. Frequency and duration of diarrhea $(\geq 3)$ or pneumonia were examined with a Poisson distribution using PROC GENMOD.

\section{RESULTS}

\section{Grain Effect}

Starter feed intake was not affected by the type of grain (CBD vs. BBD) during the preweaning (0.35 vs. $0.37 \mathrm{~kg} / \mathrm{d} ; \mathrm{SEM}=0.059, P=0.74)$, postweaning $(2.30$ vs. $2.38 \mathrm{~kg} / \mathrm{d} ; \mathrm{SEM}=0.133, P=0.54$ ), and overall $(0.79$ vs. $0.83 \mathrm{~kg} / \mathrm{d} ; \mathrm{SEM}=0.064, P=0.56)$ periods (data not shown). The type of grain did not affect $\mathrm{Cr}$ intake or health-related variables (fecal score, RR, and RT) throughout the study (Table 2). Table 3 presents the logistic models for the occurrence of diarrhea (score $\geq 3$ ) or pneumonia (d 3-94). The occurrence of diarrhea tended to be greater in BBD calves than in CBD calves (odds ratio $=1.69 ; P=0.08$ ). Calves fed BBD had a lower chance of having pneumonia compared with calves fed CBD (odds ratio $=0.49 ; P=0.01$ ). Table 4 presents the Poisson regression for the frequency and number of days with diarrhea (score $\geq 3$ ) or pneumonia. Frequency of diarrhea was not affected by the type of grain; however, number of days with diarrhea tended to be higher in calves fed BBD compared with calves fed CBD (1.29 vs. $0.75 \mathrm{~d}$ for BBD vs. CBD; $P=0.08)$. Similarly, frequency of pneumonia was not different between grain sources, but calves fed BBD experienced shorter days with pneumonia (0.88 vs. $1.50 \mathrm{~d} ; P=0.03$ ). Blood levels of BUN increased (24.73 vs. $20.23 \mathrm{mg} / \mathrm{dL}$; $P=0.01)$ in calves fed CBD during the postweaning period (Table 5). The type of grain did not affect blood levels of glucose, insulin, insulin:glucose ratio, $\mathrm{T}_{3}, \mathrm{~T}_{4}$, $\mathrm{T}_{3}: \mathrm{T}_{4}$ ratio, or cortisol at weaning and at the end of the trial (Table 6). Furthermore, basal concentrations of glucose and insulin, glucose relative disposal rate, $\mathrm{T}_{1 / 2}$, and AUC at 120 min were not affected by type of grain (Table 7). However, insulin relative disposal rate and $\mathrm{T}_{1 / 2}$ tended to increase $(3.20$ vs. $2.2 \% / \mathrm{min} ; P=0.08)$ and decrease (23.2 vs. $43.7 \mathrm{~min} ; P=0.04$ ), respectively, in CBD calves.

\section{Chromium Effect}

Supplemental Cr increased the starter feed intake during the postweaning (2.53 vs. $2.15 \mathrm{~kg} / \mathrm{d}$ for $\mathrm{Cr}$ supplementation vs. no $\mathrm{Cr}$; $\mathrm{SEM}=0.133, P=0.007$ ) and overall ( 0.88 vs. $0.74 \mathrm{~kg} / \mathrm{d}$ for Cr supplementation vs. no Cr; SEM $=0.064, P=0.03)$ periods but not before weaning ( 0.39 vs. $0.33 \mathrm{~kg} / \mathrm{d}$ for Cr supplementation vs. no $\mathrm{Cr}$; $\mathrm{SEM}=0.059, P=0.30$; data not shown). As anticipated, supplemental $\mathrm{Cr}$ increased $\mathrm{Cr}$ intake throughout the study (Table 2). Respiration rate but not RT decreased in calves supplemented with $\mathrm{Cr}$ throughout the study (Table 2). Calves supplemented with $\mathrm{Cr}$ had lower fecal score during the preweaning (2.09 vs. $2.19 ; P=0.001)$ and overall (2.18 vs. 2.27; $P=0.002)$ periods. Chromium-supplemented calves had a lower chance of having pneumonia (odds ratio $=$ 2.01; $P=0.01$ ) but similar chance of having diarrhea compared with nonsupplemented calves (Table 3). The frequency and number of days with diarrhea were not influenced by $\mathrm{Cr}$ supplementation (Table 4). Chromium supplementation resulted in fewer days with pneumonia (0.88 vs. $1.50 \mathrm{~d} ; P=0.03)$ and had no effect on the frequency of pneumonia occurrence. Calves supplemented with $\mathrm{Cr}$ tended to have lower blood levels of $3 \mathrm{HBA}$ during the preweaning $(0.091$ vs. $0.125 \mathrm{mmol} / \mathrm{L} ; P=0.10)$ and overall (0.119 vs. $0.151 \mathrm{mmol} / \mathrm{L} ; P=0.06)$ periods (Table 5). At weaning, blood levels of cortisol tended to be higher (1.49 vs. $0.67 \mu \mathrm{g} / \mathrm{dL} ; P=0.08)$ in calves supplemented with Cr (Table 6). Glucose pharmacokinetic variables were not affected by $\mathrm{Cr}$ supplementation (Table 7); however, insulin relative disappearance rate and $\mathrm{T}_{1 / 2}$ increased (3.02 vs. $\left.2.38 \% / \mathrm{min} ; P=0.01\right)$ and decreased (25.4 vs. $41.4 \mathrm{~min} ; P=0.005$ ), respectively, in Cr-supplemented calves. 
Table 2. Chromium (Cr) intake and health-related variables in calves fed corn- versus barley-based diets supplemented with or without Cr

\begin{tabular}{|c|c|c|c|c|c|c|c|c|}
\hline Item $^{1}$ & \multicolumn{4}{|c|}{ Diet $^{2}$} & SEM & \multicolumn{3}{|c|}{$P$-value } \\
\hline \multicolumn{9}{|c|}{ Cr intake, ${ }^{3} \mathrm{mg} / \mathrm{d}$} \\
\hline Preweaning & 0.095 & 0.212 & 0.089 & 0.219 & 0.017 & 0.99 & $<0.001$ & 0.71 \\
\hline Postweaning & 0.622 & 0.877 & 0.601 & 0.871 & 0.039 & 0.73 & $<0.001$ & 0.86 \\
\hline Preweaning & 2.18 & 2.05 & 2.19 & 2.12 & 0.030 & 0.17 & 0.001 & 0.41 \\
\hline Postweaning & 2.56 & 2.58 & 2.58 & 2.44 & 0.078 & 0.47 & 0.47 & 0.28 \\
\hline Overall & 2.26 & 2.17 & 2.28 & 2.19 & 0.029 & 0.51 & 0.002 & 1.00 \\
\hline \multicolumn{9}{|c|}{ Respiration rate, breaths/min } \\
\hline Preweaning & 49.5 & 43.3 & 51.2 & 44.9 & 1.28 & 0.21 & $<0.001$ & 0.97 \\
\hline Postweaning & 43.4 & 39.0 & 41.5 & 36.3 & 1.59 & 0.15 & 0.004 & 0.83 \\
\hline Overall & 48.1 & 42.3 & 49.0 & 42.9 & 1.10 & 0.52 & $<0.001$ & 0.92 \\
\hline
\end{tabular}

${ }^{1}$ Preweaning $=\mathrm{d} 3$ to 73 ; postweaning $=\mathrm{d} 74$ to 94 ; overall $=\mathrm{d} 3$ to 94.

${ }^{2}$ Diets were either a corn-based diet $(\mathrm{CBD})$ or a barley-based diet $(\mathrm{BBD})$ supplemented with $(+\mathrm{Cr})$ or without $(-\mathrm{Cr}) \mathrm{Cr}$ at $0.05 \mathrm{mg} / \mathrm{kg}$ of $\mathrm{BW}^{0.75}$.

${ }^{3}$ We have ignored the potential Cr contamination during sample preparation, from drinking water and milk, and during milk pasteurization and Cr release from feeding utensils.

${ }^{4} 1$ = firm and well-formed; $2=$ soft and pudding-like; $3=$ runny and pancake batter; $4=$ liquid and splatters (Pazoki et al., 2017).

\section{Grain × Chromium Interaction}

There was no interaction between grain source and Cr supplementation on starter feed intake during the preweaning $(0.33,0.36,0.32$, and $0.41 \mathrm{~kg} / \mathrm{d}$ for CBD without and with supplemental $\mathrm{Cr}$ and $\mathrm{BBD}$ without and with supplemental Cr, respectively; SEM $=0.059$, $P=0.66)$, postweaning $(2.13,2.46,2.17$, and $2.59 \mathrm{~kg} / \mathrm{d}$ for CBD without and with supplemental $\mathrm{Cr}$ and BBD without and with supplemental $\mathrm{Cr}$, respectively; SEM = $0.133, P=0.75)$, and overall $(0.73,0.85,0.75$, and 0.91 $\mathrm{kg} / \mathrm{d}$ for CBD without and with supplemental $\mathrm{Cr}$ and $\mathrm{BBD}$ without and with supplemental $\mathrm{Cr}$, respectively;
$\mathrm{SEM}=0.064, P=0.68$ ) periods (data not shown). The insulin disappearance rate was increased (by $57.6 \%$ / min) when BBD was supplemented with $\mathrm{Cr}(\mathrm{G} \times \mathrm{Cr}$ effect: $P=0.005$; Table 7$)$. Chromium decreased $\mathrm{T}_{1 / 2}$ $(-37.5$ min; grain $\times$ Cr effect: $P=0.003)$ and AUC $(-2,487 \mu \mathrm{IU} / \mathrm{mL} \times 120 \mathrm{~min}$; grain $\times$ Cr effect: $P=$ $0.01)$ in BBD.

\section{DISCUSSION}

Chromium concentration in the starter ingredients varies widely and has not always been reported due to the difficulty in analysis (Kargar et al., 2018b). The

Table 3. Logistic model for diarrhea (score of $\geq 3^{1}$ ) or pneumonia occurrence in calves fed a barley-based diet $(\mathrm{BBD})$ versus a corn-based diet $(\mathrm{CBD})$ or supplemented with $(\mathrm{Cr}+)$ or without $(\mathrm{Cr}-)$ chromium $(\mathrm{Cr})$ at 0.05 $\mathrm{mg} / \mathrm{kg}$ of $\mathrm{BW}^{0.75}$ during the overall period (d 3-94)

\begin{tabular}{lccccc}
\hline Variable and comparison & Coefficient & SEM & OR $^{2}$ & 95\% CI & $P$-value \\
\hline Diarrhea occurrence & 0.5258 & 0.30 & 1.69 & $0.93-3.05$ & 0.08 \\
BBD vs. CBD & 0.2325 & 0.30 & 1.26 & $0.70-2.27$ & 0.43 \\
Cr- vs. Cr+ & -0.7001 & 0.29 & 0.49 & $0.27-0.88$ & 0.01 \\
Pneumonia occurrence & 0.7010 & 0.29 & 2.01 & $1.13-3.58$ & 0.01 \\
BBD vs. CBD & &
\end{tabular}

${ }^{1} 1=$ firm and well-formed; $2=$ soft and pudding-like; $3=$ runny and pancake batter; $4=$ liquid and splatters (Pazoki et al., 2017).

${ }^{2}$ The odds ratio $(\mathrm{OR})$ indicates the probability of having either diarrhea $(\geq 3)$ or pneumonia in calves fed BBD versus $\mathrm{CBD}$ or supplemented with $(\mathrm{Cr}+)$ or without $(\mathrm{Cr}-)$ Cr. If the $\mathrm{OR}$ is $>1$, a given diet in the comparison is more likely to have occurrence of diarrhea or pneumonia than the other diet by a factor of the difference above 1 . If the OR is $<1$, a given diet has a lower probability of occurrence than the other diet. 
Table 4. Poisson regression for frequency and duration of diarrhea (score of $\geq 3^{1}$ ) or pneumonia during the overall (d 3-94) period in calves fed corn- versus barley-based diets supplemented with or without chromium $(\mathrm{Cr})$

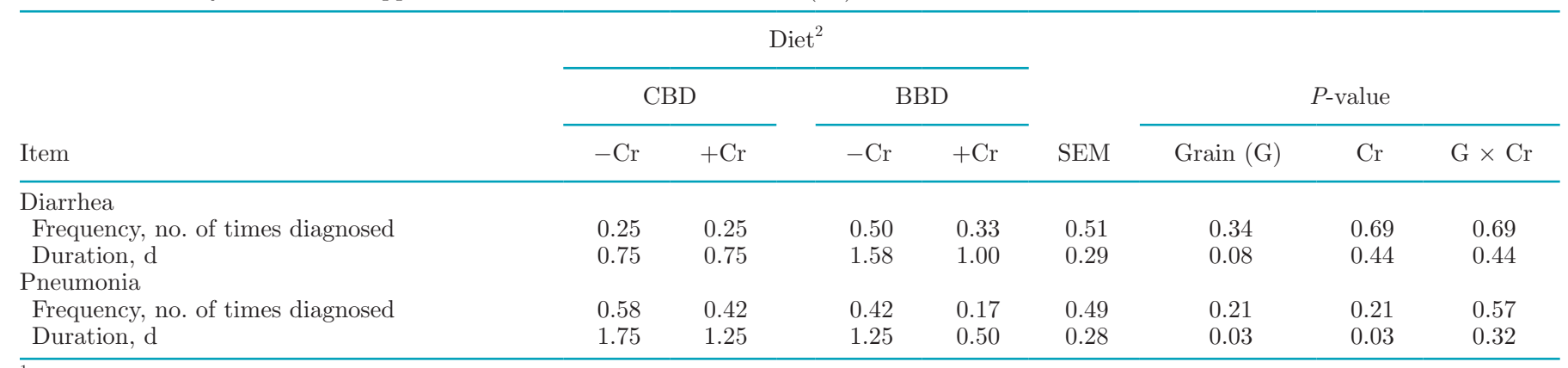

${ }^{1} 1$ = firm and well-formed; $2=$ soft and pudding-like; $3=$ runny and pancake batter; $4=$ liquid and splatters (Pazoki et al., 2017).

${ }^{2}$ Diets were either a corn-based diet $(\mathrm{CBD})$ or a barley-based diet $(\mathrm{BBD})$ supplemented with $(+\mathrm{Cr})$ or without $(-\mathrm{Cr}) \mathrm{Cr}$ at $0.05 \mathrm{mg} / \mathrm{kg}$ of $\mathrm{BW}^{0.75}$.

Table 5. Blood levels of metabolites in calves fed corn- versus barley-based diets supplemented with or without chromium (Cr)

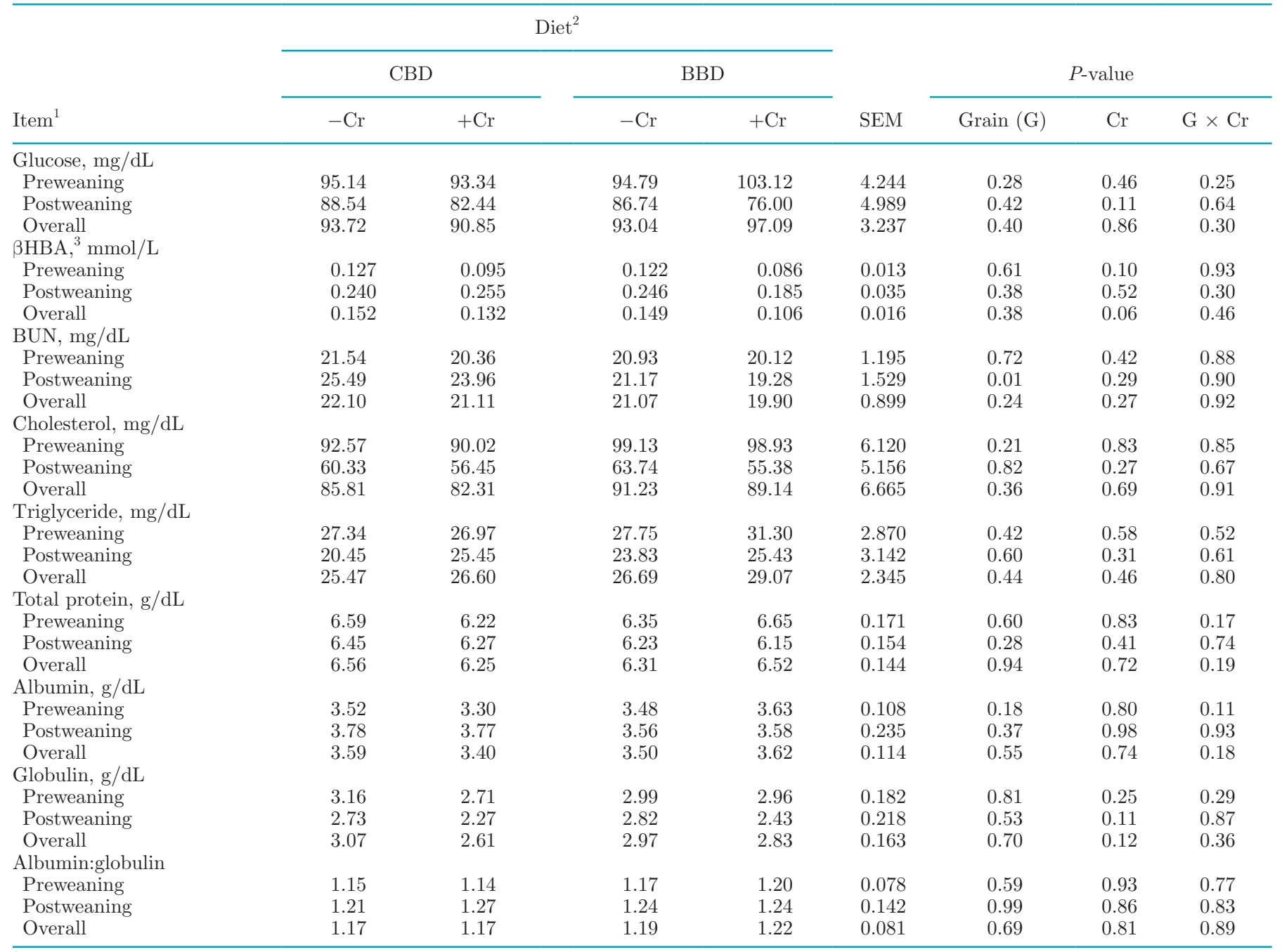

${ }^{1}$ Preweaning $=\mathrm{d} 3$ to 73 ; postweaning $=\mathrm{d} 74$ to 94 ; overall $=\mathrm{d} 3$ to 94 .

${ }^{2}$ Diets were either a corn-based diet $(\mathrm{CBD})$ or a barley-based diet $(\mathrm{BBD})$ supplemented with $(+\mathrm{Cr})$ or without $(-\mathrm{Cr}) \mathrm{Cr}$ at $0.05 \mathrm{mg} / \mathrm{kg}$ of $\mathrm{BW}^{0.75}$.

${ }^{3} \beta \mathrm{HBA}=\beta$-hydroxybutyric acid. 
Table 6. Blood levels of hormones in calves fed corn- versus barley-based diets supplemented with or without chromium (Cr)

\begin{tabular}{|c|c|c|c|c|c|c|c|c|}
\hline \multirow[b]{2}{*}{ Item $^{1}$} & \multicolumn{4}{|c|}{ Diet $^{2}$} & \multirow[b]{2}{*}{ SEM } & \multicolumn{3}{|c|}{$P$-value } \\
\hline & $-\mathrm{Cr}$ & $+\mathrm{Cr}$ & $-\mathrm{Cr}$ & $+\mathrm{Cr}$ & & Grain (G) & $\mathrm{Cr}$ & $\mathrm{G} \times \mathrm{Cr}$ \\
\hline \multicolumn{9}{|c|}{ Glucose, mg/dL } \\
\hline At weaning & 90.00 & 87.40 & 90.40 & 86.00 & 8.751 & 0.95 & 0.77 & 0.97 \\
\hline At end & 80.00 & 84.40 & 90.40 & 81.40 & 6.047 & 0.54 & 0.70 & 0.28 \\
\hline At end & 16.85 & 19.20 & 14.96 & 15.42 & 4.822 & 0.56 & 0.77 & 0.84 \\
\hline \multicolumn{9}{|l|}{ Insulin:glucose } \\
\hline At weaning & 0.15 & 0.23 & 0.17 & 0.25 & 0.057 & 0.79 & 0.19 & 0.99 \\
\hline At end & 0.14 & 0.18 & 0.16 & 0.19 & 0.045 & 0.96 & 0.36 & 0.78 \\
\hline \multicolumn{9}{|c|}{ Triiodothyronine $\left(\mathrm{T}_{3}\right), \mathrm{ng} / \mathrm{dL}$} \\
\hline At weaning & 244 & 210 & 238 & 218 & 39.7 & 0.92 & 0.75 & 0.70 \\
\hline At end & 194 & 181 & 258 & 220 & 43.5 & 0.25 & 0.56 & 0.77 \\
\hline At end & 19.68 & 22.16 & 25.02 & 23.33 & 5.330 & 0.55 & 0.94 & 0.94 \\
\hline \multicolumn{9}{|c|}{ Cortisol, $\mu \mathrm{g} / \mathrm{dL}$} \\
\hline At weaning & 0.68 & 1.44 & 0.66 & 1.54 & 0.44 & 0.93 & 0.08 & 0.89 \\
\hline At end & 1.22 & 1.78 & 1.14 & 1.30 & 0.27 & 0.31 & 0.20 & 0.47 \\
\hline
\end{tabular}

${ }^{1}$ At weaning $=\mathrm{d} 73 ;$ at end $=\mathrm{d} 93$.

${ }^{2}$ Diets were either a corn-based diet $(\mathrm{CBD})$ or a barley-based diet $(\mathrm{BBD})$ supplemented with $(+\mathrm{Cr})$ or without $(-\mathrm{Cr}) \mathrm{Cr}$ at $0.05 \mathrm{mg} / \mathrm{kg}$ of $\mathrm{BW}^{0.75}$.

starter diets in the current trial contained $0.292(\mathrm{CBD})$ and 0.277 (BBD) $\mathrm{mg}$ of $\mathrm{Cr} / \mathrm{kg}$ of DM. We have ignored the potential $\mathrm{Cr}$ contamination during sample preparation from drinking water and milk, contamination during milk pasteurization, and Cr release from feeding utensils.

In the present trial, there were tendencies for higher diarrhea occurrence and more days $(0.54 \mathrm{~d})$ with di- arrhea despite having lower chance of pneumonia and shorter days $(0.63 \mathrm{~d})$ with pneumonia in BBD versus CBD. Fecal consistency largely depends on water content and is a function of feed moisture and the mean retention time of feed in the digestive tract of animals (Kononoff et al., 2016). Diarrhea may be caused by poisoning, infection, or parasites but also may result from excessive protein intake (which increases water intake

Table 7. Glucose and insulin responses to an intravenous glucose tolerance test in calves fed corn- versus barley-based diets supplemented with or without chromium $(\mathrm{Cr})$

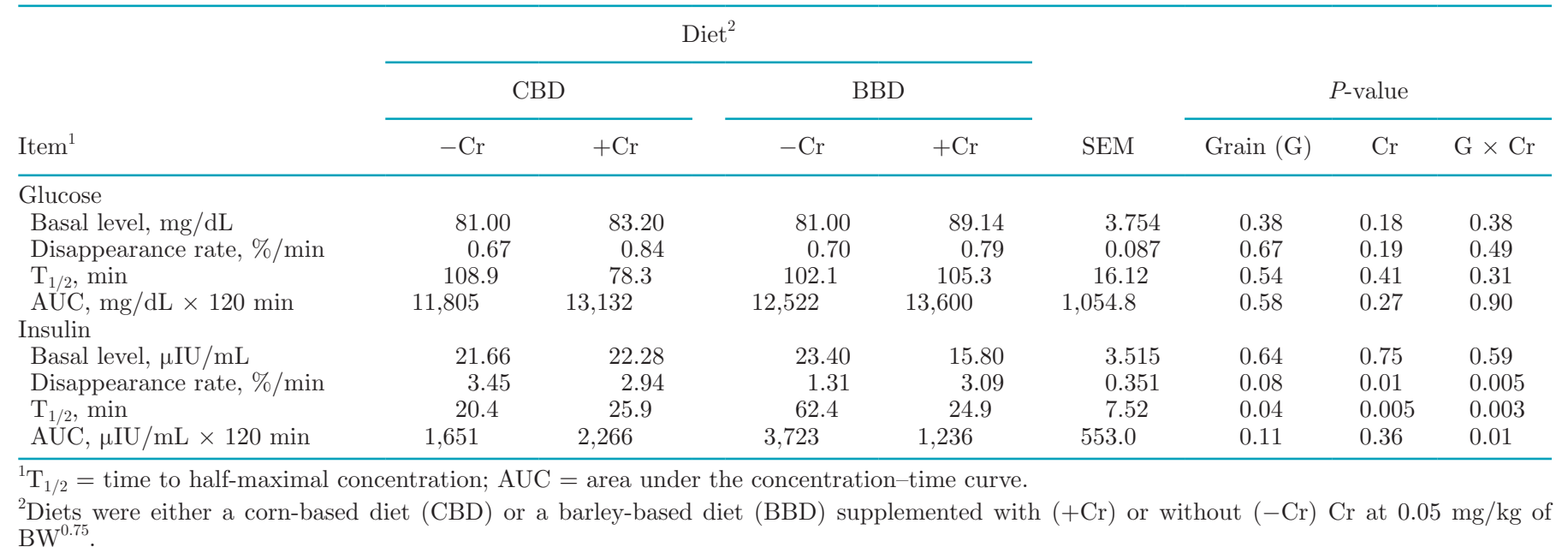


in an attempt to excrete excess $\mathrm{N}$ in urine) or extensive hindgut fermentation of carbohydrates and increased acid production (Kononoff et al., 2016). In the present trial, tendencies for increased chance of having diarrhea or more days with diarrhea in BBD calves may not be related to DM content of the basal starter feeds $(89.8 \%$, on average) or total CP intake (273 g/d, on average; data not shown) because they were almost similar between BBD and CBD. Latrille et al. (1983) showed that feeding whole barley- versus whole corn-based diets to veal calves increased starch voided in the feces (250 vs. $49 \mathrm{~g} / \mathrm{d}$ ) and thereby increased total days with diarrhea $(3.1$ vs. $1.9 \mathrm{~d})$ and fever ( 5.7 vs. $4.6 \mathrm{~d})$, possibly due to hind gut fermentation and low $\mathrm{pH}$ (Kononoff et al., 2016). In the present study, both grains were ground using a hammer mill with $2-\mathrm{mm}$ screen, and the time spent on rumination was not different between grain types during the preweaning ( 91.4 vs. $95.3 \mathrm{~min} / 12 \mathrm{~h}$ for $\mathrm{BBD}$ vs. $\mathrm{CBD}$ ) and postweaning (98.3 vs. $96.2 \mathrm{~min} / 12$ $\mathrm{h}$ for $\mathrm{BBD}$ vs. CBD) periods in the companion study (Kargar et al., 2019). However, we did not check feces for the presence of higher mucus and mucin casts or $\mathrm{pH}$ as indicators of chronic inflammation or injury in the digestive tract to ensure the excessive hind gut fermentation between the grain types. Another explanation is that calves fed BBD versus CBD had a faster eating rate ( 8.7 vs. $7.5 \mathrm{~g}$ of starter $\mathrm{DM} / \mathrm{min}$; data reported in companion study by Kargar et al., 2019) with similar intake, and therefore more days with diarrhea in calves fed BBD might be reflective of passage rate and not sickness. Khan et al. (2007) reported that calves fed $\mathrm{CBD}$ or $\mathrm{BBD}$ showed no changes in $\mathrm{RR}, \mathrm{RT}$, and days in diarrhea with no distress or illness. Pneumonia is the result of a complex interaction between the calf, its own resilience to disease and immunity, viral and bacterial pathogens, the environment, and concurrent disease (Taylor et al., 2010; Kargar and Kanani, 2019). Reasons for calves fed BBD versus CBD having a lower chance of pneumonia or fewer days with pneumonia are not clear. To our knowledge, there are no similar published data for comparison.

Supplemental Cr decreased the chance of having pneumonia and days with pneumonia. This can be related to the higher total DMI $(+140 \mathrm{~g} / \mathrm{d}$; data reported in a companion study by Kargar et al., 2019) or lower RR ( -6 breaths/min) in Cr-supplemented calves compared with nonsupplemented calves (Mowat et al., 1993; Mousavi et al., 2019b). Mowat et al. (1993) reported lower susceptibility to diseases and better response to antibiotic therapy when stressed feeder calves received organic sources of Cr. Mousavi et al. (2019b) reported that supplementing $\mathrm{Cr}$ (as Cr-Met at $0.05 \mathrm{mg} / \mathrm{kg}$ of $\mathrm{BW}^{0.75}$ ) to environmentally heat-stressed dairy calves decreased the number of days with pneumonia $(-0.92$ d) after weaning. Lower fecal score was reported earlier when $\mathrm{Cr}$ was fed to dairy calves (Ghorbani et al., 2012; Mousavi et al., 2019a). In the current trial, feeding $\mathrm{Cr}$ decreased RR, which is in line with the previous reports (Kargar et al., 2018a,b); however, a higher RR was reported in calves fed $0.03 \mathrm{mg}$ of supplemental $\mathrm{Cr} / \mathrm{kg}$ of $\mathrm{BW}^{0.75}$, although the animals remained healthy overall with no mortality (Ghorbani et al., 2012). During the present experiment, the average maximum temperature-humidity index, relative humidity, and maximum temperature were $70.3,17.4 \%$, and $27.6^{\circ} \mathrm{C}$, respectively. An upper critical temperature of $26^{\circ} \mathrm{C}$ has been indicated previously; above this temperature, calves exhibit an enhanced RR (Spain and Spiers, 1996). The average maximum temperature in the current trial was $1.6^{\circ} \mathrm{C}$ higher than the upper critical temperature, bringing about an elevated RR in calves not supplemented with Cr. The lower RR in Cr-supplemented calves might be an indication of their higher capability of coping with environmental conditions accompanied by greater health and well-being. The conserved energy might have been directed to increase the final BW (being higher in Cr-supplemented calves than in nonsupplemented calves; data reported in the companion study by Kargar et al., 2019) or used to mitigate the higher metabolic heat production due to increased feed intake (Kargar et al., 2018b).

No differences in blood concentrations of glucose, BHBA, and BUN (except after weaning) were found between $\mathrm{CBD}$ and BBD throughout the experiment, which is in agreement with Mirzaei et al. (2017) but not with Khan et al. (2007), who observed decreased circulatory glucose and increased $\beta \mathrm{HBA}$ and BUN levels in calves fed CBD versus BBD. Differences in the physical form of starter feeds (mashed vs. pelleted) or feed intake might have contributed to these discrepant findings. In a study by Khan et al. (2007), calves received pelleted starter feeds with higher feed intake for CBD versus BBD, but in Mirzaei et al. (2017), calves received mashed starter feeds with lower feed intake for CBD versus BBD. However, we observed no difference in feed intake between CBD and BBD (offered as mashed form), as reported in the companion study (Kargar et al., 2019). The blood level of BUN reflects the balance between dietary energy and nitrogen for microbial protein synthesis. The level of BUN decreases as the amount of rapidly fermenting carbohydrate increases (DePeters and Cant, 1992). The lower level of BUN observed for BBD during the postweaning period may be related to a better release of energy (synchronized) for bacterial use due to higher ruminal fermentability of starch and the consequent decreased BUN for calves fed BBD versus CBD (Khan et al., 2007). Blood levels of cholesterol, triglyceride, total protein, 
albumin, globulin, and albumin:globulin ratio were not influenced by the type of grain in the present study. This is inconsistent with Khan et al. (2007), who found higher blood levels of cholesterol, triglyceride, total protein, and albumin in calves fed CBD versus BBD. They attributed their findings to the higher starter feed intake and resultant $\mathrm{CP}$ and fat consumption in $\mathrm{CBD}$ versus $B B D$, respectively.

Blood levels of glucose, cholesterol, and triglycerides were not affected by $\mathrm{Cr}$ supplementation (Kargar et al., 2018a; Mousavi et al., 2019a,b). Yari et al. (2010) and Ghorbani et al. (2012), who observed a reduction in blood levels of cholesterol, proposed a modulatory effect of $\mathrm{Cr}$ in improving glucose tolerance, thereby decreasing circulating cholesterol levels. The current findings, however, do not indicate an effect of $\mathrm{Cr}$ on fat and cholesterol metabolism. Neither insulin:glucose ratio (as an indirect indicator of insulin responsiveness) nor pharmacokinetic characteristics in response to intravenous GTT for glucose were affected by Cr supplementation. A gradual increase in the concentration of blood $\beta$ HBA with advancing age suggested a normal physiological fuel shift in the source of energy from glucose to short-chain fatty acids with the initiation of ruminal fermentation and development in a study by Yari et al. (2010). The tendency of lower blood levels of $\beta \mathrm{HBA}$ in $\mathrm{Cr}$-supplemented calves is in line with the findings of Ghorbani et al. (2012) but not others (Kargar et al., 2018a; Mousavi et al., 2019a,b), who found no changes in blood $\beta \mathrm{HBA}$ in $\mathrm{Cr}$-supplemented calves. In adult ruminants, $\beta \mathrm{HBA}$ is derived from incomplete oxidation of fatty acids released from the mobilized energy reserves (mainly fat). During the early stages of life in the calf, glucose is used as a primary energy source; however, later on and with increased fermentation of solid feed, a large amount of $\beta \mathrm{HBA}$ is formed and the calf becomes adapted to this new nutrient as a source of energy (Quigley et al., 1991). In the present trial, as expected, the increase in $\beta \mathrm{HBA}$ concentrations in Cr-supplemented calves over time coincided with the increase in the starter feed intake. The lower blood $\beta \mathrm{HBA}$ in $\mathrm{Cr}$-supplemented calves might reflect the utilization of $\beta$ HBA (Ghorbani et al., 2012). The starter feed intake before weaning was not affected by supplemental $\mathrm{Cr}$; therefore, lower $\beta \mathrm{HBA}$ level in the Cr-supplemented group does not seem to be associated with lower ruminal production of $\beta \mathrm{HBA}$. However, starter feed intake was higher in the Cr-supplemented group during the overall period, and the calves still had lower blood $\beta$ HBA. Another explanation is that $\mathrm{Cr}$ supplementation might have promoted a reduction in 3 HBA through increased starter feed intake and activation of the immune response by increasing lymphocyte (B-cell and T-cell) proliferation index, neutrophil phagocytic activity, and blood total Ig and IgG (Kumar et al., 2015) or higher blood total protein, globulin, and antioxidant biomarkers (Kargar et al., 2018a; Mousavi et al., 2019b). However, neither the blood total protein nor globulin contents were affected by supplemental $\mathrm{Cr}$ in the present trial. Therefore, the relationship between $\mathrm{Cr}$, immune status, and blood $\beta \mathrm{HBA}$ concentration needs to be investigated further. Blood total protein and albumin contents are longer-term indicators of $\mathrm{AA}$ and immune status, whereas BUN level may more accurately reflect the short-term dietary effects on rumen $\mathrm{NH}_{3}-\mathrm{N}$ formation and hepatic $\mathrm{N}$ turnover (NRC, 2001; Yari et al., 2010). Similarly, blood globulin and albumin:globulin ratio are used to assess systemic immune function during periods when metabolic demands are high (Yari et al., 2010). In the present study, Cr supplementation did not influence the circulatory levels of BUN, total protein, albumin, globulin, and albumin: globulin ratio. This implies that no changes in the demand and competition for AA occurred and, in turn, indicates no challenge to hepatic synthesis of albumin or globulin, required to sustain nutrient transportation and normal immune function.

Ruminal digestion of starch increases the molar concentration of propionate, with the propionate being absorbed across the rumen wall and converted to glucose in the liver. Resistant starch, however, is digested in the small intestine to directly increase the circulatory glucose concentration (Kargar et al., 2013, 2014). Biologically, the site of starch digestion (rumen vs. intestine) is of interest because propionate and glucose might have different effects on metabolic hormones (Garnsworthy et al., 2009). In the present study, blood glucose and insulin levels and thereby insulin:glucose ratio at weaning and at the end of the trial were not affected by the type of grain (partly due to comparable feed intake between CBD and BBD; data reported in a companion study by Kargar et al., 2019). Therefore, it is assumed that insulin is influenced equally by the glucose absorbed from the small intestine and by the propionate absorbed across the rumen wall.

In line with Kargar et al. (2018a,b) and Mousavi et al. (2019a), the present study showed that blood levels of glucose, insulin, insulin:glucose ratio, $\mathrm{T}_{3}, \mathrm{~T}_{4}$, or $\mathrm{T}_{3}: \mathrm{T}_{4}$ ratio were not influenced by $\mathrm{Cr}$ supplementation. In line with the present findings, Cr supplementation increased blood levels of cortisol in heat-stressed calves (Yari et al., 2010). An increase in the blood level of cortisol may enable the calf to cope better with the stress associated with the weaning and transition from liquid to solid feed; this is substantiated by lower RR or higher fecal consistency in the present study. The current findings on the blood levels of cortisol and other metabolites might have been influenced by the 
potential effect of the timing of sampling at weaning and should be interpreted with caution.

There are reports in growing dairy heifers indicating that $\mathrm{Cr}$ supplementation may increase glucose disposal rate or decrease $\mathrm{T}_{1 / 2}$ (Jovanović et al., 2017; Mousavi et al., 2019b) or decrease insulin release or AUC (Yari et al., 2010; Spears et al., 2012). In the present trial, glucose kinetics data were not affected by supplementing $\mathrm{Cr}$, which is in line with previous reports by Mousavi et al. (2019a), who supplemented $0.05 \mathrm{mg}$ of Cr-Met/kg of BW to dairy calves after weaning. In a trial by Yari et al. (2010), Cr-Met supplementation decreased insulin AUC following glucose infusion without affecting glucose AUC. Area under the curve reflects both the increase in insulin concentration above basal level and the rate of insulin disappearance. Our trial is unique in that it investigated the effect of the type of grain (corn vs. barley) on insulin sensitivity in growing dairy calves. A tendency for higher insulin disappearance rate (3.2 vs. $2.2 \% / \mathrm{min})$ and thereby decreased $\mathrm{T}_{1 / 2}(23.2$ vs. 43.7 min) was observed in calves fed CBD versus BBD. Human studies have shown that the insulin response to corn was about two-thirds of that observed for wheat (Wolever et al., 1994). To our knowledge, the effect of grain type on insulin sensitivity in dairy calves has not been investigated previously. Therefore, no similar published data are available for comparison. An interesting finding in the present trial was the increased insulin sensitivity due to increased relative disappearance rate or decreased $\mathrm{T}_{1 / 2}$ and AUC in calves fed BBD supplemented with Cr. Yari et al. (2010) found a 30\% reduction in AUC (0-120 min) for insulin post-glucose infusion with no significant difference in AUC for glucose once heat-stressed postweaning dairy calves received supplemental Cr. Jovanović et al. (2017) reported a decrease in the basal levels of glucose and insulin and an increase in glucose utilization (by decreasing $T_{1 / 2}$ and glucose AUC and increasing glucose disappearance rate) when Cr-yeast was supplemented to dairy calves at $0.04 \mathrm{mg} / \mathrm{kg}$ of BW. Another report also suggested a tendency for higher glucose disappearance rate in dairy calves receiving $0.05 \mathrm{mg}$ of supplemental Cr-Met $/ \mathrm{kg}$ of BW, although insulin sensitivity was not affected (Mousavi et al., 2019b). Contradictory to the present observations, Mousavi et al. (2019a) found no significant changes in glucose or insulin kinetics following a GTT in postweaning dairy calves when Cr-Met was supplemented at $0.05 \mathrm{mg} / \mathrm{kg}$ of BW. No changes in insulin sensitivity in CBD calves were found as a result of supplemental $\mathrm{Cr}$, suggesting that $\mathrm{Cr}$ could be more effective in the diets based on rapidly versus slowly fermentable starch sources (barley vs. corn in the present study).

\section{CONCLUSIONS}

The present study indicated that neither the healthrelated variables nor blood levels of metabolites and hormones related to energy metabolism were affected by the type of grain, implying that corn and barley grains might replace each other in dairy calf starter diets until 3 mo of age when the price is competitive. Chromium supplementation increased fecal consistency, decreased RR and days with pneumonia, and thereby improved calf health status. Although tendencies for lower blood levels of $\beta \mathrm{HBA}$ and higher levels of cortisol were detected, $\mathrm{Cr}$ had no effect on energy metabolism. However, our data substantiate the beneficial effect of $\mathrm{Cr}$ supplementation on increasing insulin sensitivity in BBD but not CBD.

\section{ACKNOWLEDGMENTS}

The authors thank Shahrekord University (Shahrekord, Iran) for partially funding this research and especially for providing suitable experimental conditions. The authors express their kind appreciation to the farm staff at Zagros Milk and Meat Company (Shahrekord, Iran) for diligent animal care, to Sana Dam Company (Tehran, Iran) for donating Cr-Met, to Meysam Kanani (Shiraz University) for help in conducting statistical analyses, and to several students from the Shahrekord and Shiraz Universities completing course requirements for their input to the research and laboratory analyses. The authors also express their appreciation to Amir Akhlaghi and Mohammad Javad Zamiri (both from Shiraz University) for editing the final English version of the manuscript.

\section{REFERENCES}

DePeters, E. J., and J. P. Cant. 1992. Nutritional factors influencing the nitrogen composition of bovine milk: A review. J. Dairy Sci. 75:2043-2070.

European Food Safety Authority Panel on Dietetic Products, Nutrition, and Allergies. 2014. Scientific opinion on dietary reference values for chromium. EFSA J. 12:38.

Garnsworthy, P. C., J. G. Gong, D. G. Armstrong, G. E. Mann, K. D. Sinclair, and R. Webb. 2009. Effect of site of starch digestion on metabolic hormones and ovarian function in dairy cows. Livest. Sci. 125:161-168.

Ghorbani, A., H. Sadri, A. R. Alizadeh, and R. M. Bruckmaier. 2012 Performance and metabolic responses of Holstein calves to supplemental chromium in colostrum and milk. J. Dairy Sci. 95:57605769 .

Iranian Council of Animal Care. 1995. Guide to the Care and Use of Experimental Animals. Vol. 1. Isfahan University of Technology, Isfahan, Iran.

Jovanović, L., M. Pantelić, R. Prodanović, I. Vujanac, M. Đurić, S. Tepavčević, S. Vranješ-Đurić, G. Korićanac, and D. Kirovski. 2017. Effect of peroral administration of chromium on insulin signaling pathway in skeletal muscle tissue of Holstein calves. Biol. Trace Elem. Res. 180:223-232. 
Kargar, S., G. R. Ghorbani, V. Fievez, and D. J. Schingoethe. 2015. Performance, bioenergetic status, and indicators of oxidative stress of environmentally heat-loaded Holstein cows in response to diets inducing milk fat depression. J. Dairy Sci. 98:4772-4784.

Kargar, S., G. R. Ghorbani, M. Khorvash, E. Kamalian, and D. J. Schingoethe. 2013. Dietary grain source and oil supplement: Feeding behavior and lactational performance of Holstein cows. Livest. Sci. 157:162-172.

Kargar, S., G. R. Ghorbani, M. Khorvash, A. Sadeghi-Sefidmazgi, and D. J. Schingoethe. 2014. Reciprocal combinations of barley and corn grains in oil-supplemented diets: Feeding behavior and milk yield of lactating cows. J. Dairy Sci. 97:7001-7011.

Kargar, S., Z. Habibi, and S. Karimi-Dehkordi. 2019. Grain source and chromium supplementation: Effects on feed intake, meal and rumination patterns, and growth performance in Holstein dairy calves. Animal 13:1173-1179.

Kargar, S., and M. Kanani. 2019. Reconstituted versus dry alfalfa hay in starter feed diets of Holstein dairy calves: Effects on feed intake, feeding and chewing behavior, feed preference, and health criteria. J. Dairy Sci. 102:4061-4071.

Kargar, S., F. Mousavi, and S. Karimi-Dehkordi. 2018a. Effects of chromium supplementation on weight gain, feeding behaviour, health and metabolic criteria of environmentally heat-loaded Holstein dairy calves from birth to weaning. Arch. Anim. Nutr. $72: 443-457$.

Kargar, S., F. Mousavi, S. Karimi-Dehkordi, and M. H. Ghaffari. 2018b. Growth performance, feeding behavior, health status, and blood metabolites of environmentally heat-loaded Holstein dairy calves fed diets supplemented with chromium. J. Dairy Sci. 101:9876-9887.

Khan, M. A., H. J. Lee, W. S. Lee, H. S. Kim, S. B. Kim, K. S. Ki, S. J. Park, J. K. Ha, and Y. J. Choi. 2007. Starch source evaluation in calf starter: I. Feed consumption, body weight gain, structural growth, and blood metabolites in Holstein calves. J. Dairy Sci. 90:5259-5268.

Kononoff, P., J. Heinrichs, and G. Varga. 2016. Using manure evaluation to enhance dairy cattle nutrition. Technical Bulletin of The Pennsylvania State University, College of Agriculture Science, Cooperative Extension: DAS 02-51. Department of Dairy and Animal Science, The Pennsylvania State University, University Park.

Kumar, M., H. Kaur, R. Sarma-Deka, V. Mani, A. Kumar-Tyagi, and G. Chandra. 2015. Dietary inorganic chromium in summerexposed buffalo calves (Bubalus bubalis): Effects on biomarkers of heat stress, immune status, and endocrine variables. Biol. Trace Elem. Res. 167:18-27.

Latrille, L., J. P. Paré, G. St-Laurent, and C. Pomar. 1983. Heavy veal production with Holstein calves raised by multiple suckling or milk replacers and fattened with whole corn, barley or oats. Can. J. Anim. Sci. 63:643-653.

Mader, T. L., M. S. Davis, and T. Brown-Brandl. 2006. Environmental factors influencing heat stress in feedlot cattle. J. Anim. Sci. 84:712-719.
Mirzaei, M., M. Khorvash, G. R. Ghorbani, M. Kazemi-Bonchenari, and M. H. Ghaffari. 2017. Growth performance, feeding behavior, and selected blood metabolites of Holstein dairy calves fed restricted amounts of milk: No interactions between sources of finely ground grain and forage provision. J. Dairy Sci. 100:1086-1094.

Mousavi, F., S. Karimi-Dehkordi, S. Kargar, and M. H. Ghaffari. 2019a. Effect of chromium supplementation on growth performance, meal pattern, metabolic and antioxidant status and insulin sensitivity of summer-exposed weaned dairy calves. Animal 13:968-974.

Mousavi, F., S. Karimi-Dehkordi, S. Kargar, and M. KhosraviBakhtiari. 2019b. Effects of dietary chromium supplementation on calf performance, metabolic hormones, oxidative status, and susceptibility to diarrhea and pneumonia. Anim. Feed Sci. Technol. 248:95-105.

Mowat, D. N., X. Chang, and W. Z. Yang. 1993. Chelated chromium for stressed feeder calves. Can. J. Anim. Sci. 73:49-55.

NRC. 2001. Nutrient Requirement of Dairy Cattle. 7th rev. ed. Natl. Acad. Sci., Washington, DC.

Pazoki, A., G. R. Ghorbani, S. Kargar, A. Sadeghi-Sefidmazgi, J. K. Drackley, and M. H. Ghaffari. 2017. Growth performance, nutrient digestibility, ruminal fermentation, and rumen development of calves during transition from liquid to solid feed: Effects of physical form of starter feed and forage provision. Anim. Feed Sci. Technol. 234:173-185.

Pechova, A., and L. Pavlata. 2007. Chromium as an essential nutrient: A review. Vet. Med. 52:1-18.

Quigley, J. D.. L. A. Caldwell, G. D. Sinks, and R. N. Heitmann. 1991. Changes in blood glucose, non-esterified fatty acids, and ketones in response to weaning and feed intake in young calves. J. Dairy Sci. 74:250-257.

Spain, J. N., and D. E. Spiers. 1996. Effects of supplemental shade on thermoregulatory response of calves to heat challenge in a hutch environment. J. Dairy Sci. 79:639-646.

Spears, J. W., C. S. Whisnant, G. B. Huntington, K. E. Lloyd, R. S. Fry, K. Krafka, A. Lamptey, and J. Hyda. 2012. Chromium propionate enhances insulin sensitivity in growing cattle. J. Dairy Sci. 95:2037-2045.

Taylor, J. D., R. W. Fulton, T. W. Lehenbauer, D. L. Step, and A. W. Confer. 2010. The epidemiology of bovine respiratory disease: What is the evidence for predisposing factors? Can. Vet. J. 51:1095-1102.

Wolever, T. M. S., L. Katzman-Relle, A. L. Jenkins, V. Yuksan, R. G. Josse, and D. J. A. Jenkins. 1994. Glycaemic index of 102 complex carbohydrate foods in patients with diabetes. Nutr. Res. 14:651-669.

Yari, M., A. Nikkhah, M. Alikhani, M. Khorvash, H. Rahmani, and G. R. Ghorbani. 2010. Physiological calf responses to increased chromium supply in summer. J. Dairy Sci. 93:4111-4120. 